\title{
Adulthood Lesion
}

National Cancer Institute

\section{Source}

National Cancer Institute. Adulthood Lesion. NCI Thesaurus. Code C60643.

A benign or malignant lesion arising during adulthood. 